\title{
Powdery Mildew-Infection Changes Bacterial Community Composition in the Phyllosphere
}

\author{
WATARU SUDA ${ }^{1}$, AsAmi NAGASAKI $^{1}$, and MASAHIRO SHISHIDO ${ }^{1 *}$ \\ ${ }^{1}$ Graduate School of Horticulture, Chiba University, 648 Matsudo, Matsudo-shi, Chiba 271-8510, Japan \\ (Received February 17, 2009—Accepted April 19, 2009—Published online June 25, 2009)
}

To investigate changes in bacterial communities associated with a fungal foliar disease, epiphytic bacteria from powdery mildew-infected and uninfected leaves of cucumber and Japanese spindle were analyzed using both culturedependent and -independent methods. Dilution plate counting suggested that powdery mildew-infected leaves likely accommodated larger populations of phyllosphere bacteria than uninfected leaves. Community-level physiological profiles (CLPP) also indicated that functional diversity, richness, and evenness of bacterial communities were significantly greater in the phyllosphere of powdery mildew-infected leaves. Genotype diversity and richness based on band patterns of denaturing gradient gel electrophoresis (DGGE) of the phyllosphere bacterial community were greater for leaves infected by powdery mildew. A principle component analysis of CLPP and DGGE patterns revealed a clear difference between infected and uninfected leaves of both plant species. These results suggest that powdery mildew-infection results in larger bacterial populations, and greater diversity and richness, and also changes the structure of the phyllosphere bacterial community. Furthermore, DNA sequences of the DGGE bands that showed greater intensity in the infected than uninfected leaves, differed between cucumber and Japanese spindle. This suggests that specific bacteria are associated with the plant species accompanying this fungal infection.

Key words: powdery mildew, phyllosphere, epiphytic bacteria, denaturing gradient gel electrophoresis (DGGE), community-level physiological profile (CLPP)

The phyllosphere is the above-ground surface of a plant, and is represented by the leaves. It provides habitats for various microorganisms including bacteria, fungi, and yeasts (20). Epiphytic bacteria are the main inhabitants of the phyllosphere, and are estimated to have a density of $10^{6}-10^{7}$ CFU cm$~^{-2}$ on a typical leaf (20). Culture-based studies have shown that such bacteria may include plant pathogens, ice nucleation-active bacteria, decomposers, phytohormoneproducers, nitrogen fixers, and antagonists of plant pathogens $(8,10,11,14,25,35)$. Traditionally, bacterial communities in the phyllosphere were thought to be highly variable in both quantity and quality $(9,13,33)$. Moreover, Yang et al. (37) demonstrated that based on culture-independent analyses of $16 \mathrm{~S}$ ribosomal RNA gene (=16S rDNA), bacterial communities on leaves were more diverse than had been predicted from culture-based studies.

In addition to bacteria, many fungal species have been isolated from the phyllosphere. These fungi are often observed as airborne spores on healthy leaves (3), and several of them also grow on the leaves. Some fungal species have evolved an ability to invade leaf tissues, causing foliar diseases. Although interactions between foliar fungal pathogens and their host plants have been well documented (21), little is known about the relationships between fungi and bacterial communities on leaves.

In contrast, relationships between fungi and bacterial communities in the rhizosphere have been well studied. For example, root colonization of arbuscular mycorrhizal (AM) fungi increases the population sizes, activities, and composi-

\footnotetext{
* Corresponding author. E-mail: shishido@faculty.chiba-u.jp; Tel: +81-47-308-8824; Fax: +81-47-308-8824.
}

tion of rhizosphere bacterial communities (15). A fungal pathogen also altered the structure of rhizosphere bacterial communities (38). Therefore, it is of interest whether fungal leaf colonization changes the nature of phyllosphere microbial communities.

Powdery mildew is one of the most common foliar diseases, infecting more than 650 monocot and more than 9,000 dicot species worldwide resulting in severe economic losses (29). The causal agents of this disease belong to the order Erysiphales of the phylum Ascomycota, which includes 18 genera and 435 species (6). Each of the species tends to have a narrow host range, often restricted to one plant species (39). For example, the powdery mildews of cucumber (Cucumis sativus L.) and Japanese spindle (Euonymus japonicus Thunb.) are caused by Podosphaera xanthii or Erysiphe cichoracearum and Oidium euonymi-japonica, respectively (5).

To evaluate the effects of powdery mildew infection on bacterial communities in the phyllosphere, we investigated the bacterial communities on cucumber and Japanese spindle. We used both culture-dependent and culture-independent techniques, including community-level physiological profiling (CLPP) and polymerase chain reaction-denaturing gradient gel electrophoresis (PCR-DGGE) of $16 \mathrm{~S}$ rDNA. The hypothesis of this study was that powdery mildew infection changes the quantity and quality of bacterial communities in the phyllosphere.

\section{Materials and Methods}

Plants and leaf samples

Leaf samples were collected from the campus of Chiba Univer- 
sity in summer, 2007. Leaves of cucumber (C. sativus) were collected from cultivated plants in an experimental field, and leaves of Japanese spindle (E. japonicus) were collected from garden hedge trees. No pesticide was sprayed before sampling, and powdery mildew infection occurred naturally on both plant species. The anamorphic stage of powdery mildew when mycelia were spread over more than a half of the leaf area was sampled. Leaf samples were divided into powdery mildew-infected and uninfected leaves, placed into polyethylene bags, and immediately stored at $4^{\circ} \mathrm{C}$. All analytical procedures were carried out within $24 \mathrm{~h}$.

\section{Phyllosphere microbial suspensions}

Microorganisms in the phyllosphere of cucumber and Japanese spindle were harvested from leaf surfaces using the sonication-wash method (37). Each sample consisted of $150 \mathrm{~cm}^{2}$ of leaf material, with or without powdery mildew infection. Three replicates were prepared for cucumber, and four for Japanese spindle. Leaf samples were gently rinsed with sterilized distilled water to remove dust from the leaf surface, and submerged in sterilized $0.1 \mathrm{M}$ potassium phosphate buffer ( $\mathrm{pH} 7.0)$ in a sterilized polypropylene tube. The tube was sonicated for $7 \mathrm{~min}$ using an ultrasonic cleaner (VS-100, AS ONE, Osaka, Japan). Microorganisms released into the buffer were pelleted by centrifugation at $20,000 \times \mathrm{g}$ for $15 \mathrm{~min}$, and then resuspended in $2 \mathrm{~mL}$ of fresh potassium phosphate buffer.

\section{Dilution plate counting of culturable bacteria in the phyllosphere}

The dilution plating method was used to estimate the population size of culturable bacteria in the phyllosphere. Each aliquot of microbial suspension $(100 \mu \mathrm{L})$ was serially diluted with sterilized $0.1 \mathrm{M}$ potassium phosphate buffer $(\mathrm{pH} 7.0)$, and spread onto 0.1 strength yeast peptone sucrose agar $(0.1 \%$ yeast extract, $0.1 \%$ Bacto Peptone, $0.5 \%$ sucrose, and $1.5 \%$ agar) containing $100 \mu \mathrm{g} \mathrm{mL}^{-1}$ of cycloheximide. Bacterial colonies on each plate were enumerated after incubation for 3 days at $28^{\circ} \mathrm{C}$.

\section{Community-level physiological profile (CLPP) analysis}

A community-level physiological profile (CLPP) of phyllosphere microbial communities in each sample was determined using EcoPlate $^{\mathrm{TM}}$ (Biolog, Hayward, CA, USA). The EcoPlate ${ }^{\mathrm{TM}}$ contains 31 different carbon sources; 10 carbohydrates, 7 carboxylic acids, 4 polymers, 6 amino acids, 2 amines and 2 phenolic compounds, replicated three times on each microplate of 96 wells. The phyllosphere microbial suspensions $(500 \mu \mathrm{L})$ were diluted with sterilized $0.1 \mathrm{M}$ potassium phosphate buffer ( $\mathrm{pH} 7.0)$ to $10 \mathrm{~mL}$. An aliquot $(140 \mu \mathrm{L})$ of the dilution was inoculated into each well of the microplate. The microplates were incubated in the dark at $28^{\circ} \mathrm{C}$ for 4 days. Color development of the solutions was measured as optical density (OD) at $590 \mathrm{~nm}$ with a micro-plate reader (MTP-100, Corona Electric, Katsuta, Japan) after 24, 48, 72, and $96 \mathrm{~h}$. All OD readings were adjusted using the reading for a blank well (10 mM phosphate buffer control), and negative values were set to zero. Data were normalized by the average well color development (AWCD) of all 31 substrates for each sample as recommended by Garland and Mills (12).

\section{Metagenomic DNA extraction}

To obtain metagenomic DNA from phyllosphere microbial communities, $1 \mathrm{~mL}$ of microbial suspension was collected by centrifugation at $20,000 \times \mathrm{g}$ for $15 \mathrm{~min}$, and DNA was extracted using the lysozyme cell-lysis and bead-beating method (24). The centrifuged pellets were resuspended in $750 \mu \mathrm{L}$ of lysis buffer $(100 \mathrm{mM}$ sodium phosphate buffer [ $\mathrm{pH} 8.0]$ containing $5 \mathrm{mg} \mathrm{mL}^{-1}$ lysozyme), incubated at $37^{\circ} \mathrm{C}$ for $15 \mathrm{~min}$, and disrupted in a tube containing $750 \mathrm{mg}$ of glass beads $(0.1 \mathrm{~mm}$ in diameter, BioSpec products, Bartlesville, OK) using a bead-beater (BioSpec Products) at 5,000 rpm for $90 \mathrm{~s}$. After $45 \mu \mathrm{L}$ of $20 \%$ sodium dodecyl sulfate and $700 \mu \mathrm{L}$ of Trisbuffered phenol ( $\mathrm{pH}$ 8.0) were added, the mixture was vortexed and centrifuged at $10,000 \times g$ for $10 \mathrm{~min}$. The aqueous phase was collected, mixed with an equal volume of chloroform, and centrifuged again under the same conditions. DNA was recovered from the aqueous phase by precipitation with isopropanol. After washing with $70 \%$ ethanol and air-drying, the DNA was solved in $200 \mu \mathrm{L}$ of TE buffer [10 mM Tris-HCl, 1 mM EDTA (pH 8.0)].

\section{PCR-DGGE analysis of 16S rRNA gene}

PCR was performed in $50 \mu \mathrm{L}$ volumes containing $200 \mu \mathrm{M}$ dNTP, 0.5 U Ampli Taq Gold (Applied Biosystems, Foster City, CA), $10 \mathrm{mM}$ Tris- $\mathrm{HCl}$ (pH 8.3), $50 \mathrm{mM} \mathrm{KCl,} 2.5 \mathrm{mM} \mathrm{MgCl}_{2}, 0.5$ $\mu \mathrm{M}$ of primers designed for amplification of the $\mathrm{V} 3$ region of $16 \mathrm{~S}$ rRNA gene (16S rDNA), and $2 \mu \mathrm{L}$ of extracted metagenomic DNA. The specific primers were PRBA338f (5'-ACTCCTACGGGAGGCAGCAG-3') (18) and PRUN518r (5'-ATTACCGCGGCTGCTGG-3') (26). For DGGE, a 40 bp GC-clamp (5'-CGCCCGCCGCGCGCGGCGGGCGGGGCGGGGGCACGGGGGG-3') was linked at the $5^{\prime}$ end of PRBA338f (26). Reaction conditions were as follows: $10 \mathrm{~min}$ of initial preheating at $94^{\circ} \mathrm{C}, 38$ cycles of $94^{\circ} \mathrm{C}$ for $15 \mathrm{~s}, 55^{\circ} \mathrm{C}$ for $45 \mathrm{~s}, 72^{\circ} \mathrm{C}$ for $30 \mathrm{~s}$, and a final extension at $72^{\circ} \mathrm{C}$ for 7 min. PCR was carried out using a GeneAmp ${ }^{\circledR}$ PCR system 2700 (Applied Biosystems). PCR products of approximately $200 \mathrm{bp}$ were visually confirmed by electrophoresis on $4.0 \%(\mathrm{w} / \mathrm{v})$ agarose gels prior to the DGGE procedure.

PCR products $(40 \mu \mathrm{L})$ were separated by DGGE using a DCode $^{\mathrm{TM}}$ Universal Mutation Detection System (Bio-Rad Laboratories, Hercules, CA). The samples were applied to $8 \%$ polyacrylamide gels containing a linear gradient of $30-60 \%$ denaturant ( $100 \%$ denaturant defined as $7 \mathrm{M}$ urea and $40 \%$ formamide). Conditions for electrophoresis were as follows: $170 \mathrm{~V}$ for 6 hours at $60^{\circ} \mathrm{C}$; running buffer, $40 \mathrm{mM}$ Tris, $20 \mathrm{mM}$ acetate, and $1 \mathrm{mM} \mathrm{Na} \mathrm{mDDT}_{2}$ $(\mathrm{pH} 7.4)(1 \times \mathrm{TAE}$ buffer). After the electrophoresis, gels were stained with ethidium bromide and viewed by UV rans-illumination. The images were transformed into digital data using the Densitograph gel documentation system (ATTO, Tokyo, Japan). The position and intensity of each band were converted to numerical values using ImageJ 1.37v (National Institute of Health, USA).

\section{Sequencing and identification of bacteria}

DNA sequences were determined for major bands in the DGGE gels. Separated DNA bands were cut from the gels and eluted in $30 \mu \mathrm{L}$ of TE buffer overnight at $4^{\circ} \mathrm{C}$. The eluted DNA was reamplified by PCR using the primers PRBA338f (without a GCclamp) and PRUN518r under the conditions described above. The sequences of the re-amplified DNA fragments were determined using a DNA sequencing kit (Big Dye Terminator V3.1, Applied Biosystems) and a DNA sequencer (ABI PRISM 3100 Genetic Analyzer, Applied Biosystems). Similarity searches for the determined sequences were performed using the basic local alignment search tool (BLAST) on the National Center for Biotechnology Information web server.

\section{Statistical analyses of CLPP and DGGE data}

After normalization, CLPP data based on 48-h readings of Biolog ${ }^{\mathrm{TM}}$ substrate utilization were used for analyses of substrate diversity $\left(H^{\prime}\right)$, richness $(R I)$, and evenness $\left(J^{\prime}\right)(23,40)$. $H^{\prime}$ 'was calculated based on a concept analogous to Shannon's diversity index $\left[H^{\prime}=-\Sigma P i \ln P i\right.$, where $P i=(\mathrm{OD}$ reading of well $\underline{i}) /($ sum of all wells)]. $R 1$ was based on Margalef's richness index $[R l=(S-1) /$ $\ln (n)$, where $S$ is the total number of substrates utilized and $n=$ total OD reading]. $J^{\prime}$ was based on Pielou's evenness index [ $\left.J^{\prime}=H^{\prime} / \ln S\right]$. Similarly, the relative distances and intensity values of DGGE bands were used to analyze genotype diversity $\left(H^{\prime}\right)$, richness $(R l)$, and evenness $\left(J^{\prime}\right)$.

To characterize the microbial community composition of each sample, the CLPP and DGGE data were subjected to a principal components analysis (PCA) with the covariance matrix. Before the PCA, normalized CLPP data were log-transformed as recommended by Weber et al. (34). In addition, carbon substrates responsible for more than 5\% of the CLPP profiles' variability under the influence of the factors of host plant and the powdery mildew infec- 
tion were determined based on the eigenvector coefficients for PC 1 and PC 2 loadings after varimax rotation. All of the statistical analyses were conducted using JMP ${ }^{\mathrm{TM}}$ 5.0.1J (SAS Institute Japan, Tokyo, Japan).

\section{Nucleotide sequence accession numbers}

The sequences obtained in this study were submitted to the DNA Data Bank of Japan and have been assigned the following accession numbers: AB459542 to AB459550.

\section{Results}

\section{Population sizes of culturable bacteria in the phyllosphere}

The population of culturable bacteria detected in the cucumber phyllosphere was slightly larger on powdery mildew-infected leaves than healthy (uninfected) leaves, but the difference was statistically insignificant: $2.61 \pm 0.326 \times$ $10^{5} \mathrm{CFU} \mathrm{cm} \mathrm{cm}^{-2}$ and $1.73 \pm 0.444 \times 10^{5} \mathrm{CFU} \mathrm{cm}^{-2}$ (mean $\pm \mathrm{SE}$, $p=0.110$ by Student's $t$ test), respectively. On the other hand, the population size of culturable bacteria on Japanese spindle was significantly greater on the powdery mildew-infected leaves than uninfected leaves: $7.98 \pm 1.57 \times 10^{5}$ and $1.52 \pm$ $0.34 \times 10^{3}$ (mean \pm SE, $p<0.01$ by Student's $t$ test), respectively. Although powdery mildew infection tended to increase bacterial population sizes for both plant species, the disease had a greater impact on the phyllosphere bacterial community of Japanese spindle than cucumber. In Japanese spindle, the number of culturable bacteria was approximately 525 times greater on the infected leaves than healthy leaves, whereas in cucumber, the number was 1.5 times greater.

\section{CLPP analysis}

A principal component analysis of the CLPP patterns indicated distinct differences among bacterial communities on the four types of leaves (two host species $\times$ diseased/healthy), as classified by their use of carbon sources (Fig. 1). The PCA plot showed that the first component mainly distinguished powdery mildew infection $(29.7 \%)$, while the second component explained the host species difference $(22.2 \%)$. The difference in bacterial communities in the phyllopshere influenced by the powdery mildew infection was more pronounced in Japanese spindle than in cucumber in the first component. On the other hand, the bacterial communities on cucumber leaves differed from those on Japanese spindle leaves more on healthy leaves than on powdery mildewinfected leaves, as shown in the second component. In addition, healthy Japanese spindle leaves had relatively larger sample variations in the phyllosphere communities than the diseased leaves.

Substrates with a factor loading of more than $5 \%$ of the total eigenvector coefficient after varimax rotation in Fig. 1 are presented in Table 1. The listed substrates are therefore more than 5\% responsible for differentiation along the first and second components in the PCA plot. Polymers such as $\alpha$-cyclodextrin, Tween 40 , and Tween 80 , in addition to Lphenylalanine, 4-hydroxy benzoic acid, and $i$-erythritol, were responsible for the positive direction of the first component, whereas glycogen solely accounted for its negative direction. Similarly, two carbolic acids, D-galacturonic acid and Dmalic acid; two amino acids, L-arginine and L-asparagine; and two carbohydrates, D-xylose and $i$-erythritol, were respon-

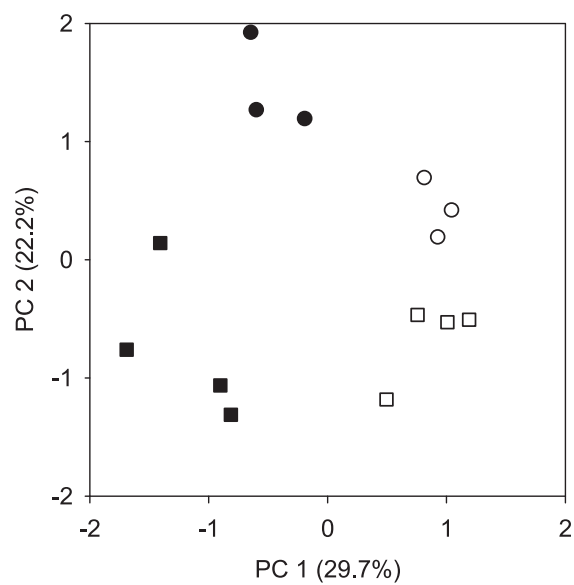

Fig. 1. Ordination plot of principal components (PC) 1 and 2 from community level physiological profiles (CLPP) of bacterial communities derived from the cucumber (circle) and Japanese spindle (square) phyllospheres. CLPP were established from carbon substrate utility patterns obtained using Biolog Ecoplates ${ }^{\mathrm{TM}}$. Filled and empty symbols indicate healthy (uninfected) and diseased (powdery mildew-infected) leaves, respectively.

Table 1. Carbon substrates responsible for the variability in CLPP of the phyllosphere bacterial community of cucumber and Japanese spindle leaves with or without infection by powdery mildew based on the eigenvector coefficients associated with PC 1 and PC 2 of a principal component analysis ${ }^{\mathrm{a}}$

\begin{tabular}{|c|c|c|c|c|}
\hline Substrate $^{\mathrm{b}}$ & PC 1 & $(\%)$ & PC 2 & $(\%)$ \\
\hline \multicolumn{5}{|l|}{ Carbohydrates } \\
\hline$\beta$-Methyl-D-Glucoside & - & - & -0.240 & $(8.0)$ \\
\hline D-Xylose & - & - & 0.171 & $(5.7)$ \\
\hline Glucose-1-Phosphate & - & - & -0.162 & $(5.4)$ \\
\hline$i$-Erythritol & 0.147 & $(6.0)$ & 0.231 & $(7.7)$ \\
\hline $\mathrm{N}$-Acetyl-D-Glucosamine & - & - & -0.223 & (7.4) \\
\hline \multicolumn{5}{|l|}{ Carboxylic acids } \\
\hline D-Galacturonic Acid & - & - & 0.313 & $(10.4)$ \\
\hline D-Malic Acid & - & - & 0.226 & $(7.5)$ \\
\hline \multicolumn{5}{|l|}{ Polymers } \\
\hline$\alpha-C y c l o d e x t r i n$ & 0.178 & $(7.3)$ & - & - \\
\hline Glycogen & -0.304 & $(12.5)$ & - & - \\
\hline Tween 40 & 0.203 & $(8.3)$ & - & - \\
\hline Tween 80 & 0.222 & $(9.1)$ & - & - \\
\hline \multicolumn{5}{|l|}{ Amino acids } \\
\hline L-Arginine & - & - & 0.187 & $(6.2)$ \\
\hline L-Asparagine & - & - & 0.257 & $(8.6)$ \\
\hline L-Phenylalanine & 0.232 & $(9.5)$ & - & - \\
\hline \multicolumn{5}{|l|}{ Phenolic compounds } \\
\hline 4-Hydroxy Benzonic Acid & 0.175 & $(7.2)$ & - & - \\
\hline
\end{tabular}

a The result of the principal component analysis for CLPP is presented in Fig. 1.

${ }^{b}$ Substrates with factor loadings $|x|>5 \%$ of total eigenvector coefficients after varimax rotation are presented.

sible for the positive direction of the second component, while three carbohydrates, $\beta$-methyl-D-glucoside, glucose-1phosphate, and N-acetyl-D-glucosamine, were major contributors to its negative direction.

\section{$D G G E$ analysis}

DGGE profiles of the PCR products from metagenomic DNA of cucumber leaves consisted of many bands (Fig. 2A). 
A

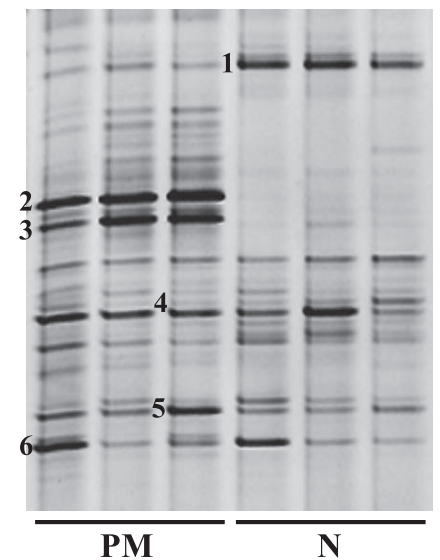

B

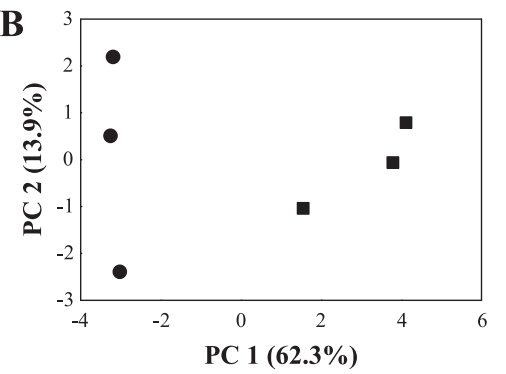

Fig. 2. DGGE profiles of $16 \mathrm{~S}$ rRNA genes derived from cucumber phyllosphere bacterial communities. (A) PM: powdery mildew-infected leaves. N: uninfected (healthy) leaves. Ordination plot of principal components (PC) 1 and 2 from the DGGE band patterns shown above. (B)

口: Powdery mildew infected leaves. O: uninfected leaves.

Table 2. Identification of major DGGE bands shown in Figs. 2 and 3

\begin{tabular}{|c|c|c|c|}
\hline $\begin{array}{l}\text { Band } \\
\text { position }\end{array}$ & Data base match (accession number) & $\underset{(\%)}{\text { Similarity }}$ & $\begin{array}{c}\text { Accession } \\
\text { number }\end{array}$ \\
\hline 1 & $\begin{array}{l}\text { Cucumis sativus 18S rRNA gene } \\
\text { (AF206894) }\end{array}$ & 100 & - \\
\hline 2 & $\begin{array}{l}\text { Exiguobacterium acetylicum 16S rRNA } \\
\text { gene (D55730) }\end{array}$ & 100 & AB459542 \\
\hline 3 & $\begin{array}{l}\text { Exiguobacterium sp. 16S rRNA gene } \\
\text { (EF101987) }\end{array}$ & 99 & AB459543 \\
\hline 4 & $\begin{array}{l}\text { Curtobacterium sp. 16S rRNA gene } \\
\text { (EU741030) }\end{array}$ & 100 & AB459544 \\
\hline 5 & $\begin{array}{l}\text { Microbacterium sp. 16S rRNA gene } \\
(\text { EF612295) }\end{array}$ & 100 & AB459545 \\
\hline 6 & $\begin{array}{l}\text { Microbacterium testaceum 16S rRNA } \\
\text { gene (AF526917) }\end{array}$ & 100 & AB459546 \\
\hline 7 & $\begin{array}{l}\text { Taxeobacter sp. 16S rRNA gene } \\
\text { (EU379243) }\end{array}$ & 92 & AB459547 \\
\hline 8 & $\begin{array}{l}\text { Curtobacterium sp. 16S rRNA gene } \\
\text { (EU741030) }\end{array}$ & 100 & AB459548 \\
\hline 9 & $\begin{array}{l}\text { Deinococcus sp. 16S rRNA gene } \\
\text { (EU308577) }\end{array}$ & 99 & AB459549 \\
\hline 10 & $\begin{array}{l}\text { Deinococcus sp. 16S rRNA gene } \\
\text { (EU427464) }\end{array}$ & 97 & AB459550 \\
\hline
\end{tabular}

There were 17 bands in profiles from powdery mildewinfected leaves, and 13-14 bands in profiles from uninfected leaves. The PCA plot based on these DGGE profiles confirmed the difference between the infected and uninfected leaves in the first component (Fig. 2B). The nucleotide sequences of six bands dominant in these profiles were determined and compared with gene databases (Table 2, band positions 1-6). The powdery mildew-infected leaves showed
A
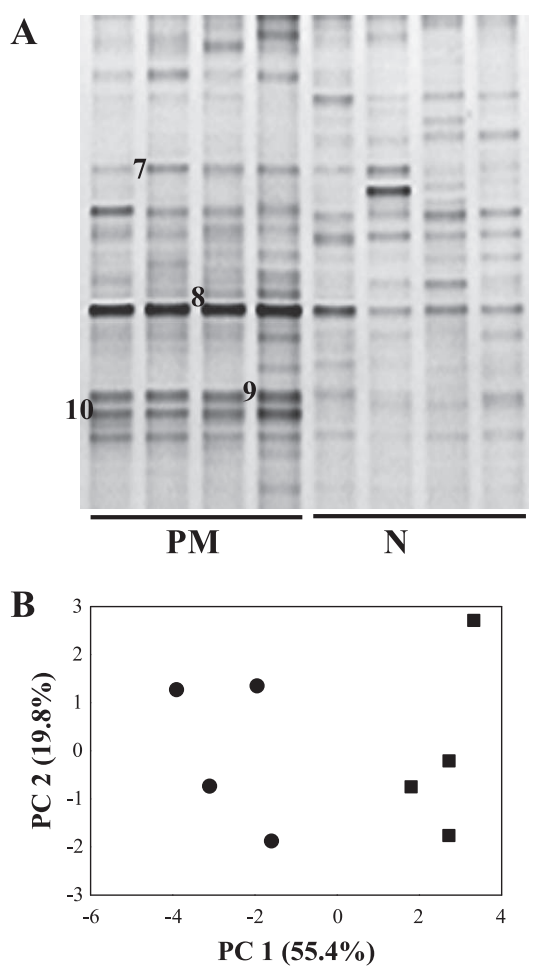

Fig. 3. DGGE profiles of $16 \mathrm{~S}$ rRNA genes derived from Japanese spindle phyllosphere bacterial communities. (A) PM: powdery mildewinfected leaves. N: uninfected (healthy) leaves. Ordination plot of principal components (PC) 1 and 2 from the DGGE band patterns shown above. (B) $\mathbf{\square}$ : Powdery mildew-infected leaves. O: uninfected leaves.

two dominant bands (bands 2 and 3) that were absent in the profiles of uninfected leaves. The sequences of bands 2 and 3 exhibited $100 \%$ and $98 \%$ similarity, respectively, to the Exiguobacterium acetylicum $16 \mathrm{~S}$ rRNA gene.

DGGE profiles from metagenomic DNA extracted from leaf-samples of Japanese spindle are shown in Fig. 3A. Similar to the cucumber leaves, more bands were observed in the profiles of powdery mildew-infected leaves (11-12) than those of uninfected leaves (9-10). Unlike in cucumber leaves, no completely unique bands were detected in the powdery mildew-infected leaves, but the individual bands tended to be stronger in the infected leaves than in the uninfected leaves. The PCA plot based on the DGGE profiles of Japanese spindle leaves also revealed a difference in the first component between the infected and uninfected leaves (Fig. 3B). The nucleotide sequences of four major bands in these profiles were determined and compared with gene databases (Table 2, band positions 7-10). The sequence of band 8 , which showed the highest intensity in the profiles of the powdery mildew-infected leaves, showed $100 \%$ homology to the Curtobacterium sp. 16S rRNA gene.

\section{Functional and genotype diversity based on CLPP and $D G G E$}

Powdery mildew infection significantly impacted on functional diversity, as shown by the different carbon substrates utilized by the phyllosphere bacterial communities, and on genotype diversity, as shown by the DGGE profiles. The host plant species did not affect either of these factors (Table 3). 
Table 3. Bacterial community diversity, richness and evenness as indicated from community level physiological profiling (CLPP) and denaturing gradient gel electrophoresis (DGGE) in the phyllosphere of cucumber and Japanese spindle with or without infestation of powdery mildew

\begin{tabular}{|c|c|c|c|c|c|c|c|}
\hline & \multicolumn{3}{|c|}{ CLPPa $^{a}$} & & \multicolumn{3}{|c|}{$\mathrm{DGGE}^{\mathrm{b}}$} \\
\hline & Diversity $^{\mathrm{c}}$ & Richness $^{\mathrm{c}}$ & Evenness $^{\mathrm{c}}$ & & Diversity $^{\mathrm{c}}$ & Richness $^{\mathrm{c}}$ & Evenness $^{\mathrm{c}}$ \\
\hline \multicolumn{8}{|l|}{ Host plant } \\
\hline Japanese spindle leaves & 2.356 & 4.989 & 0.838 & & 2.974 & 2.839 & 1.2559 \\
\hline \multicolumn{8}{|l|}{ Powdery mildew infection } \\
\hline Infected leaves & 2.924 & 6.823 & 0.919 & & 3.033 & 3.411 & 1.1965 \\
\hline Source of variation & & & & $P$-values & & & \\
\hline Host plant & 0.0850 & 0.3053 & 0.0689 & & 0.0578 & 0.0002 & $<0.0001$ \\
\hline Powdery mildew infection & 0.0030 & 0.0211 & 0.0149 & & 0.0003 & $<0.0001$ & 0.0002 \\
\hline Host plant $\times$ Powdery mildew infection & 0.0554 & 0.2197 & 0.0616 & & 0.2031 & 0.0078 & 0.5943 \\
\hline
\end{tabular}

${ }^{a}$ Community level physiological profiling (CLPP) was used as an indicator of functional diversity based on the carbon source utilization patterns (48 $\mathrm{h}$ data) obtained in the BIOLOG analysis.

b Genotype diversity of bacterial communities was used as an indicator of bacterial diversity based on the banding patterns obtained using DGGE.

c Shannon's index, Margalef's index, and Pielou's index were used for diversity, richness, and evenness indices, respectively (23).

Carbon source utilization patterns were more diverse, and a greater variety of substrates was used by the bacterial community on powdery mildew-infected leaves, compared with that on uninfected leaves. Bacterial genotypes revealed by DGGE were also more diverse in the infected phyllosphere than uninfected phyllosphere. Similar trends in diversity indices were observed among the richness of carbon substrates used, and among genotypes revealed by DGGE. Powdery mildew infection resulted in significantly greater richness values for both CLPP and DGGE. The evenness index values varied between host species and between infection status.

\section{Discussion}

The size and nature of the phyllosphere bacterial community fluctuates with changes in the host plant and in the environment (7). Leaf age can influence both the size and structure of the phyllosphere bacterial community $(9,20,33)$. For example, Thompson et al. (33) reported that significantly greater microbial numbers were detected on senescing primary leaves than on mature and immature leaves. In our study, to minimize the influence of leaf age, we collected mature leaves of the same size from powdery mildewinfected and uninfected plants.

The size of the culturable population of bacteria in the healthy cucumber phyllosphere was greater than that in the Japanese spindle phyllosphere. This result was consistent with those of previous studies, in which grasses or waxy broad leaf plants (e.g. corn and barley) generally had smaller bacterial populations than broad-leaf plants such as cucumber and bean $(17,20,27)$. Interestingly, bacterial population size clearly increased with powdery mildew infection for Japanese spindle. Cucumber leaves also showed an increase in the culturable bacterial population size but the magnitude was not large enough to be statistically significant. Although mature leaves with similar infection rates were sampled for both plant species, the periods that the powdery mildew fungi resided on the host leaves might have been different because Japanese spindle is an ever-green tree whereas cucumber is a fast growing annual. If the powdery mildew of Japanese spindle leaves developed for a longer period than that of cucumber leaves, the former had a greater advantage to accumulate bacterial populations associated with the infection. Therefore, the results of this experiment suggest that a foliar disease such as powdery mildew increases the population sizes of bacteria associated with the disease, especially in slow-growing plants that otherwise have smaller bacterial populations.

To characterize the qualitative differences between the phyllosphere bacterial communities, we performed both a culture-dependent CLPP analysis with Biolog EcoPlates ${ }^{\mathrm{TM}}$ and a culture-independent PCR-DGGE analysis of 16S rDNA. Combining the polyphasic data sets generally gives a better understanding of the community (36). The CLPP analysis revealed a clear difference in the first component of the PCA plot between powdery mildew infected and uninfected leaves of both cucumber and Japanese spindle, while the second component separated these two plant species (Fig. 1). Because $\alpha$-cyclodextrin, Tween 40, Tween 80, L-phenylalanine, 4-hydroxy benzoic acid, and $i$-erythritol were major contributors to the positive direction of the first component, any bacterial group that can utilize these substrates is likely associated with powdery mildew. In contrast, glycogen contributed to the negative direction of the first component; therefore, glycogen decomposers are unlikely associated with this foliar disease. The PCA plot based on the DGGE band patterns also clearly revealed a difference in the first component between infected and uninfected leaves for both cucumber and Japanese spindle (Figs. 2B and 3B). These results suggest that powdery mildew-infection not only enhances bacterial population sizes in the phyllosphere but also drastically changes the bacterial community structure.

We were also interested in determining the relationships between powdery mildew infection and changes in bacterial functional diversity as indicated by carbon substrate utilization patterns, and bacterial genotype diversity as indicated by DGGE. Regardless of host plant species, both of these indi- 
ces clearly increased as a result of powdery mildew infection. Each method of measuring diversity is selective: CLPP relies on substrate utilization by culturable populations of bacteria, while DGGE detects DNA fragments of nonculturable bacteria (22). Although these measures target different aspects of bacterial communities, precise bacterial populations in the phyllosphere cannot be directly measured. Therefore, our results indicate general trends showing that powdery mildew infection increases bacterial diversity and richness on leaves.

Among the DNA fragments re-amplified from the dominant DGGE bands, all of them showed a high degree of similarity to previously described rRNA genes (97-100\%), except for band 7 which had only $92 \%$ similarity (Table 2). Such low similarity to any previously described $16 \mathrm{~S}$ rRNA gene suggests this band to be derived from an unreported bacterium. The DNA sequence of band 1 showed $100 \%$ homology with the 18S rRNA gene of cucumber (Cucumis sativus), indicating that genomic DNA of the host plant was co-extracted. Contamination with host plant DNA is not uncommon in culture-independent $16 \mathrm{~S}$ rDNA-based analyses of phyllosphere microbial communities (31). Though we used a washing-based method to minimize contamination, it was difficult to completely eliminate host plant DNA from the cucumber leaf samples.

Some bands in the DGGE profiles of bacterial communities from both cucumber and Japanese spindle phyllospheres showed greater intensity in samples from infected leaves than those from healthy leaves. In the cucumber leaves, bands 2 and 3 were more intense (Fig. 2), and in Japanese spindle, band 8 was stronger (Fig. 3). The increased intensity suggests that powdery mildew infection increases numbers of specific bacteria in the phyllosphere. The DNA sequences of these DGGE bands differed between cucumber and Japanese spindle leaves. In the cucumber phyllosphere, sequences of bands 2 and 3 were homologous to the $16 \mathrm{~S}$ rRNA gene of Exiguobacterium sp., which has been isolated from the phyllosphere only rarely (16). In the Japanese spindle phyllosphere, the sequence of band 8 was closely related to the 16S rRNA gene of Curtobacterium sp., which is frequently isolated from the phyllosphere (e.g. 19, 32). Interestingly, the sequence of band 4 in the cucumber phyllosphere was exactly the same as that of band 8 , one of the dominant bands in the powdery mildew-infected Japanese spindle leaves. However, band 4 was observed in all DGGE profiles of cucumber leaves and its intensity was similar regardless of infection status. These results suggest some degree of specificity between powdery mildew fungi and the bacterial community associated with them.

It is well established that colonization by arbuscular mycorrhizal (AM) fungi affects the nature of rhizospheric bacterial communities (15). Total bacterial populations in the rhizosphere were greater in plants colonized by AM fungi than in non-colonized plants $(1,30)$. AM fungi can also influence bacterial community composition, because differences in the bacterial communities were found among different AM fungal species (28). These characteristics of the rhizosphere bacterial communities are similar to those of the phyllosphere counterparts found in this study. In the rhizosphere, AM fungi change root exudation patterns, resulting in different bacterial community structures $(2,4)$.

In the phyllosphere, however, the driving forces and mechanisms that underlie the changes in bacterial communities remain unclear, because few studies have reported interactions among host plants, fungal infection, and bacterial communities. Two explanations for the changes in phyllosphere bacterial communities are conceivable: (a) certain metabolites secreted by powdery mildew-fungi directly affected bacterial composition, and (b) powdery mildewinfection altered the chemical and/or physiological conditions of leaves which influenced the colonization and growth of epiphytic bacteria. To test these hypotheses, further investigations are needed to elucidate relationships between chemical or physiological conditions of leaves and phyllosphere microbial communities associated with foliar pathogeninfection. A better understanding of foliar-disease ecology as such may provide more efficient ways of managing plant diseases in the future.

In conclusion, based on both culture-dependent and independent methods, we have demonstrated the changes of the phyllosphere bacterial community associated with powdery mildew infection, including increases in population size, and functional and genotype diversity, and changes in substrate utilization patterns and community structure. These findings support our hypothesis that powdery mildew infection changes the quantity and quality of bacterial communities in the phyllosphere.

\section{Acknowledgements}

This research was supported by a Grant-in-aid for Scientific Research (18580040) from the Japan Society for the Promotion of Science. We thank Drs. Y. Amemiya, T. Usami, S. Amachi, and M. Oto for their valuable advice.

\section{References}

1. Ames, R.N., C.P.P. Reid, and E.R. Ingham. 1984. Rhizosphere bacterial population responses to root colonization by a vesiculararbuscular mycorrhizal fungus. New Phytol. 96:555-563.

2. Andrade, G., R.G. Linderman, and G.J. Bethlenfalvay. 1998. Bacterial associations with the mycorrhizosphere and hyphosphere of the arbuscular mycorrhizal fungus Glomus mosseae. Plant Soil 202:7987.

3. Andrews, J.H., and R.F. Harris. 2000. The ecology and biogeography of microorganisms on plant surfaces. Annu. Rev. Phytopathol. 38:145-180.

4. Azaizeh, H.A., A. Marschner, V. Römheld, and L. Wittenmayer. 1995. Effects of a vesicular-arbuscular mycorrhizal fungus and other soil microorganisms on growth, mineral nutrient acquisition and root exudation of soilgrown maize plants. Mycorrhiza 5:321-327.

5. Belanger, R.R., W.R. Bushnell, A.J. Dik, and T.L.W. Carver. 2002. The Powdery Mildews: A Comprehensive Treatise. APS press, St. Paul, MN, USA.

6. Braun, U. 1987. A monograph of the Erysiphales (powdery mildews). Beiheft zur Nova Hedwigia 89:1-760.

7. Dickinson, C.H. 1986. Adaptation of microorganisms to climatic conditions affecting aerial plant surfaces, p. 77-100. In N.J. Fokkema, and J. van den Heuvel (ed.), Microbiology of the Phyllosphere. Cambridge University Press, Cambridge, UK.

8. Enya, J., H. Shinohara, S. Yoshida, T. Tsukiboshi, H. Negishi, K. Suyama, and S. Tsushima. 2007. Culturable leaf-associated bacteria on tomato plants and their potential as biological control agents. Microb. Ecol. 53: 524-536.

9. Ercolani, G.L. 1991. Distribution of epiphytic bacteria on olive leaves and the influence of leaf age and sampling time. Microb. Ecol. 21:3548 . 
10. Fett, W.F., S.F. Osman, and M.F. Dunn. 1987. Auxin production by plant-pathogenic pseudomonads and xanthomonads. Appl. Environ. Microbiol. 53:1839-1845.

11. Fürnkranz, M., W. Wanek, A. Richter, G. Abell, F. Rasche, and A. Sessitsch. 2008. Nitrogen fixation by phyllosphere bacteria associated with higher plants and their colonizing epiphytes of a tropical lowland rainforest of Costa Rica. ISME J. 2:561-570.

12. Garland, J.L., and A.L. Mills. 1991. Classification and characterization of heterotrophic microbial communities on the basis of patterns of community-level sole-carbon-source utilization. Appl. Environ. Microbiol. 57:2351-2359.

13. Hirano, S.S., and C.D. Upper. 1989. Diel variation in population size and ice nucleation activity of Pseudomonas syringae on snap bean leaflets. Appl. Environ. Microbiol. 55:623-630.

14. Hirano, S.S., and C.D. Upper. 2000. Bacteria in the leaf ecosystem with emphasis on Pseudomonas syringae-a pathogen, ice nucleus, and epiphyte. Microbiol. Mol. Biol. Rev. 64:624-653.

15. Johansson, J.F., L.R. Paul, and R.D. Finlay. 2004. Microbial interactions in the mycorrhizosphere and their significance for sustainable agriculture. FEMS Microbiol. Ecol. 48:1-13.

16. Kadivar, H., and A.E. Stapleton. 2003. Ultraviolet radiation alters maize phyllosphere bacterial diversity. Microb. Ecol. 45:353-361.

17. Kinkel, L.L., M. Wilson, and S.E. Lindow. 2000. Plant species and plant incubation conditions influence variability in epiphytic bacterial population size. Microb. Ecol. 39:1-11.

18. Lane, D.J. 1991. 16S/23S rRNA sequencing, p. 115-175. In E. Stackebrandt, and M. Goodfellow (ed.), Nucleic Acid Techniques in Bacterial Systematic. John Wiley and Sons, West Sussex, UK.

19. Legard, D.E., M.P. McQuilken, J.M. Whipps, J.S. Fenlon, T.R. Fermor, I.P. Thompson, M.J. Bailey, and J.M. Lynch. 1994. Studies of seasonal changes in the microbial populations on the phyllosphere of spring wheat as a prelude to the release of a genetically modified microorganism. Agric. Ecosyst. Environ. 50:87-101.

20. Lindow, S.E., and M.T. Brandl. 2003. Microbiology of the phyllosphere. Appl. Environ. Microbiol. 69:1875-1883.

21. Lipka, U., R. Fuchs, and V. Lipka. 2008. Arabidopsis non-host resistance to powdery mildews. Curr. Opin. Plant Biol. 11:404-411.

22. Liu, B., M.L. Gumpertz, S. Hu, and J.B. Ristaino. 2007. Long-term effects of organic and synthetic soil fertility amendments on soil microbial communities and the development of southern blight. Soil. Biol. Biochem. 39:2302-2316.

23. Ludwig, J.A., and J.F. Reynolds. 1988. Statistical Ecology: A Primer on Methods and Computing. John Wiley and Sons, New York, NY, USA.

24. Milling, A., N.C. Gomes, O. Sichler, M. Götz, and K. Smalla. 2005. Nucleic acid extraction from environmental samples, p. 11-16. In A.J. Osborn, and C.J. Smith (ed.), Molecular Microbial Ecology. Taylor and Francis, USA.

25. Morris, C.E., and L.L. Kinkel. 2002. Fifty years of phyllosphere microbiology: Significant contributions to research in related fields, p. 365-375. In S.E. Lindow, I. Hecht-Poinar, and V. Elliott (ed.) Phyllosphere Microbiology. APS Press, St. Paul, MN, USA.
26. Muyzer, G., E.C. de Waal, and A.G. Uitterlinden. 1993. Profiling of complex microbial populations by denaturing gradient gel electrophoresis analysis of polymerase chain reaction-amplified genes coding for 16S rRNA. Appl. Environ. Microbiol. 59:695-700.

27. O’Brien, R.D., and S.E. Lindow. 1989. Effect of plant species and environmental conditions on epiphytic population sizes of Pseudomonas syringae and other bacteria. Phytopathology 79:619627.

28. Schreiner, R.P., K.L. Mihara, H. McDaniel, and G.J. Bethlenfalvay. 1997. Mycorrhizal fungi influence plant and soil functions and interactions. Plant. Soil. 188:199-209.

29. Schulze-Lefert, P., and J. Vogel. 2000. Closing the ranks to attack by powdery mildew. Trends Plant Sci. 5:343-348.

30. Secilia, J., and D.J., Bagyaraj. 1987. Bacteria and actinomycetes associated with pot cultures of vesicular arbuscular mycorrhizas. Can. J. Microbiol. 33:1069-1073.

31. Suda, W., M. Oto, S. Amachi, H. Shinoyama, and M. Shishido. 2008. A direct method to isolate DNA from phyllosphere microbial communities without disrupting leaf tissues. Microbes. Environ. 23:248-252.

32. Sundin, G.W., and J.L. Jacobs. 1999. Ultraviolet radiation (UVR) sensitivity analysis and UVR survival strategies of a bacterial community from the phyllosphere of field-grown peanut (Arachis hypogeae L.). Microb. Ecol. 38:27-38.

33. Thompson, I.P., M.J. Bailey, J.S. Fenlon, T.R. Fermor, A.K. Lilley, J.M. Lynch, P.J. McCormack, M.P. McQuilken, and K.J. Purdy. 1993. Quantitative and qualitative seasonal changes in the microbial community from the phyllosphere of sugar beet (Beta vulgaris). Plant Soil 150:177-191.

34. Weber, K.P., J.A. Grove, M. Gehder, W.A. Anderson, and R.L. Legge. 2007. Data transformations in the analysis of community-level substrate utilisation data from microplates. J. Microbiol. Methods. 69:461-469.

35. Weyman-Kaczmarkowa, W., and Z. Pedziwilk. 2001. Epiphytic microflora of poplar clones susceptible and resistant to infection by Dothichiza populea. Microbiol. Res. 156:83-86.

36. Widmer, F., A. Fließbach, E. Laczkó, J. Schulze-Aurich, and J. Zeyer. 2001. Assessing soil biological characteristics: A comparison of bulk soil community DNA-, PLFA-, and Biolog-analyses. Soil Biol. Biochem. 33:1029-1036.

37. Yang, C.H., D.E. Crowley, J. Borneman, and N.T. Keen. 2001. Microbial phyllosphere populations are more complex than previously realized. Proc. Natl. Acad. Sci. USA 98:3889-3894.

38. Yang, C.H., D.E. Crowley, and J.A. Menge. 2001. 16S rDNA fingerprinting of rhisosphere bacterial communities associated with healthy and Phytophthora infected avocado roots. FEMS Microbiol. Ecol. 35:129-136.

39. Yarwood, C.E. 1978. History and taxonomy of powdery mildews, p. 1-37. In D.M. Spencer (ed.), The Powdery Mildews. Academic Press, London, UK.

40. Zak, J.C., M.R. Willig, D.L. Moorhead, and H.G. Wildman. 1994. Functional diversity of microbial communities: A quantitative approach. Soil. Biol. Biochem. 26:1101-1108. 